\title{
Trends in sexual behaviour and risk factors for HIV infection among homosexual men, 1984-7
}

\author{
Brian A Evans, Kenneth A McLean, Stephen G Dawson, Steven A Teece, Robert A Bond, \\ Kenneth D MacRae, Robert W Thorp
}

\begin{abstract}
To assess whether the spread of infection with HIV can be reduced by changes in behaviour among groups most at risk because of their sexual practices sexual behaviour was monitored among 1050 homosexual men tested for HIV infection at a genitourinary medicine clinic in west London from November 1984 to September 1987. Four cohorts, defined by date of presentation, were studied by questionnaire at their presentation, and blood samples were analysed.
\end{abstract}

Between the first and last cohorts there was a considerable fall in the proportion reporting casual relationships $(291 / 329(88 \%) v 107 / 213(50 \%))$ and high risk activities, such as anoreceptive intercourse with casual partners $(262 / 291(90 \%) v 74 / 106(70 \%))$, with the greatest changes occurring before the government information campaign began in 1986 . Nevertheless, half of the men in the last cohort studied reported having casual partners. Multiple logistic regression showed that behavioural risk factors for HIV infection most closely resembled those for hepatitis $B$ and that previous sexually transmitted diseases (syphilis, hepatitis B, and anogenital herpes) were themselves independent risk factors. A history of syphilis ranked above anoreceptive intercourse as the strongest predictor of HIV infection. Actively bisexual men showed a much lower prevalence of HIV infection $(3 / 57,5 \%)$ than exclusively homosexual men $(113 / 375,30 \%)$.

Sexual behaviour among homosexual men changed during the period studied, and the incidence of HIV infection fell, although more education programmes directed at homosexual men are needed to re-emphasise the dangers of infection.

\section{Introduction}

The rapid spread of infection with HIV among homosexual men has been strongly associated with anoreceptive intercourse practised with multiple partners. ${ }^{1-4} \mathrm{By}$ contrast, anopenetrative intercourse is not associated with HIV infection. Thus role reversal has been necessary to create an epidemic. Organisations formed by homosexual men have advocated safer sexual practices, and the press and news media have brought AIDS to the attention of the general public. Moreover, in the United Kingdom the government began a programme of health education in March 1986, which culminated in the postal delivery of a leaflet to every household in January 1987. Subsequently, the newly formed Health Education Authority took over the role of advertising the dangers of infection and the routes by which HIV is transmitted. The specific dangers facing homosexual men have not been highlighted by these official campaigns.
We followed the trends in male homosexual behaviour and associated sexually transmitted infections, previously reported in a study carried out from November 1984 to May 1985,', during the period covering the three years ending September 1987.

\section{Subjects and methods}

All homosexual and bisexual men attending the department of genitourinary medicine at the West London Hospital who, after suitable counselling, wished to be tested for HIV infection were asked to complete a standardised self administered questionnaire comprising 14 questions, and the response was checked for completeness.' The study started in November 1984, which coincided with the availability of a test for HIV antibody carried out by the Virus Reference Laboratory at the Public Health Laboratory Service, Colindale.

To observe trends in sexual behaviour and other variables the study group was divided into four cohorts by period of presentation. The first cohort (329 men) were those outpatients who presented from 22 November 1984 to 30 June 1985; the second cohort (296 men) presented from 1 July 1985 to 31 March 1986; the third (212 men) presented from 1 April to 31 December 1986; and the fourth (213 men) presented from 1 January to 30 September 1987 . Thus the first cohort was obtained over a slightly shorter period than the others; this was justified by the backlog of patients who were waiting for the test to become available.

Specimens of serum were tested for HIV antibody by two radioimmunoassays, competitive radioimmunoassay and IgG capture radioimmunoassay, and a commercial enzyme linked immunoadsorbent assay (ELISA) ((Elavia, Pasteur) or Abbott)). Reactions were confirmed by positive results in multiple assays including, when necessary, western blotting. ${ }^{6}$ Tests for infection with hepatitis $B$ were a radioimmunoassay for hepatitis B surface antibody and reverse passive haemagglutination for hepatitis B surface antigen. Previous infection with syphilis was detected by the Treponema pallidum haemagglutination test.

Multiple logistic regression was used to obtain estimates of relative risk for associations between possible risk factors (box) and HIV infection, hepatitis $B$, and syphilis. 'Variables were scored $0=$ no, $1=$ yes. Forward stepwise regression was used with $\mathrm{p}<0.05$ as the criterion for inclusion in the model. Changes over the four periods of presentation were tested for significance with the $\chi^{2}$ test for trend. ${ }^{8}$

\section{Results}

A total of 1050 homosexual and bisexual men were recruited to the study from November 1984 to

Dr Evans. 
September 1987. Table I shows numbers in each of the four cohorts together with the percentage who were positive for HIV antibody.

\section{CONSISTENCY BETWEEN COHORTS}

To establish whether the fall in the proportion of men infected with HIV in each successive cohort was due to inherent differences in the men who came for testing we compared the characteristics of the patients in each cohort (table II). None of the following showed any trend over time: previous heterosexual experience, a regular sexual partner for more than six months, the age of the patients, and the duration for which they had practised a homosexual lifestyle. On the other hand, variables relating to numbers and nature of male sexual partners all showed a significant $(p<0.001)$ downward trend (table II), though in the final cohort half of the men still reported having current sexual relationships with casual partners.

\section{RELATIVE RISKS FOR INFECTION}

Multivariate analysis of our data by stepwise logistic regression was carried out to determine the relative risks for the three main infections acquired by homosexual men: HIV, hepatitis B, and syphilis (table III). The five behavioural variables independently related to infection with HIV differed in two respects from those reported in our previous study. Sexual relationships with European partners was no longer an independent risk, and anopenetrative fisting was replaced by anoreceptive fisting. The greatest risks remained anoreceptive intercourse and a large number of sexual partners. Multiple partners was an important risk factor for all three infections, but anoreceptive intercourse did not constitute an independent risk for syphilis, nor did the use of drugs during intercourse.

TABLE I - Distribution of homosexual men positive for HIV antibody in successive cohorts

\begin{tabular}{lcccc}
\hline & \multicolumn{4}{c}{ Period of presentation } \\
\cline { 2 - 5 } & $\begin{array}{c}\text { Now 1984 to } \\
\text { June 1985 }\end{array}$ & $\begin{array}{c}\text { July 1985 to } \\
\text { March 1986 }\end{array}$ & $\begin{array}{c}\text { April to } \\
\text { Dec 1986 }\end{array}$ & $\begin{array}{c}\text { Jan to } \\
\text { Sept 1987 }\end{array}$ \\
\hline $\begin{array}{l}\text { No in cohort } \\
\text { No }(\%) \text { positive for HIV antibody }\end{array}$ & $\begin{array}{l}329 \\
105(32)\end{array}$ & $\begin{array}{c}296 \\
71(24)\end{array}$ & $\begin{array}{c}212 \\
52(25)\end{array}$ & $\begin{array}{c}213 \\
44(21)\end{array}$
\end{tabular}

TABLE II-Changes in variables assessed in homosexual men in successive cohorts. Figures are numbers (percentages) except where stated

\begin{tabular}{|c|c|c|c|c|}
\hline \multirow[b]{2}{*}{ Variable } & \multicolumn{4}{|c|}{ Period of presentation } \\
\hline & $\begin{array}{l}\text { Nov } 1984 \text { to } \\
\text { June } 1985 \\
(\mathrm{n}=329)\end{array}$ & $\begin{array}{l}\text { July } 1985 \text { to } \\
\text { March } 1986 \\
(\mathrm{n}=296)\end{array}$ & $\begin{array}{l}\text { April to } \\
\text { Dec 1986 } \\
(\mathrm{n}=212)\end{array}$ & $\begin{array}{l}\text { Jan to } \\
\text { Sept 1987 } \\
(\mathbf{n}=213)\end{array}$ \\
\hline \multicolumn{5}{|c|}{ Variables stable throughout study } \\
\hline $\begin{array}{l}\text { Mean age (years) } \\
\text { Ever been heterosexual } \\
\text { Had regular partner for }>6 \text { months } \\
\text { Homosexual for }<3 \text { years }\end{array}$ & $\begin{array}{c}33 \cdot 3 \\
222(67) \\
159(48) \\
30(9)\end{array}$ & $\begin{array}{c}32 \cdot 6 \\
196(66) \\
150(51) \\
37 / 295(13)\end{array}$ & $\begin{array}{c}32 \cdot 9 \\
125 / 211(59) \\
105 / 211(50) \\
25(12)\end{array}$ & $\begin{array}{c}33 \cdot 0 \\
131(62) \\
109(51) \\
28(13)\end{array}$ \\
\hline \multicolumn{5}{|c|}{ Downward trend in number of partners $(p<0.001)$} \\
\hline $\begin{array}{l}\text { Current casual partners } \\
\text { European partner within past } 2 \text { years } \\
\text { American partner within past } 2 \text { years } \\
>20 \text { Partners in past year }\end{array}$ & $\begin{array}{r}291(88 ; \\
196(60) \\
123(37) \\
77(23)\end{array}$ & $\begin{array}{c}210(71) \\
130(44) \\
71(24) \\
34 / 295(12)\end{array}$ & $\begin{array}{r}118(56) \\
69(33) \\
42(20) \\
15(7)\end{array}$ & $\begin{array}{r}107(50) \\
59(28) \\
35(16) \\
16(8)\end{array}$ \\
\hline \multicolumn{5}{|c|}{ Dowwnward trend in independent risk factors } \\
\hline $\begin{array}{l}\text { Homosexual for }>5 \text { years } \\
\text { Anoreceptive intercourse } \\
\text { Current anoreceptive intercourse } \\
>50 \text { Partners throughout life } \\
\text { Current use of drugs during intercourse } \\
\text { Anoreceptive fisting } \\
\text { Current anoreceptive fisting }\end{array}$ & $\begin{array}{c}262(80) \\
280(85) \\
262 / 291(90) \\
251(76) \\
219(67) \\
48 / 328(15) \\
42 / 290(14)\end{array}$ & $\begin{array}{l}229 / 295(78) \\
209(71) \\
163 / 210(78) \\
187 / 294(64) \\
151(51) \\
22 / 291 \quad(8) \\
15 / 206 \quad(7)\end{array}$ & $\begin{array}{l}160(75) \\
134 / 211(64) \\
93 / 117(80) \\
110(52) \\
71(33) \\
14 / 207(7) \\
10 / 115(9)\end{array}$ & $\begin{array}{l}157(74) \\
137 / 211(65) \\
74 / 106(70) \\
106(50) \\
75 / 212(35) \\
11 / 210(5) \\
5 / 105(5)\end{array}$ \\
\hline \multicolumn{5}{|c|}{ Downward trend in sexually transmitted infections } \\
\hline $\begin{array}{l}\text { Hepatitis B infection } \dagger \\
\text { Syphilis } \\
\text { HIV }\end{array}$ & $\begin{array}{l}201 / 325(62) \\
122(37) \\
105(32)\end{array}$ & $\begin{array}{r}151(51) \\
90(30) \\
72(24)\end{array}$ & $\begin{array}{r}102(48) \\
51(24) \\
52(25)\end{array}$ & $\begin{array}{c}87 / 208(42) \\
51 / 211(24) \\
44(21)\end{array}$ \\
\hline
\end{tabular}

${ }^{\star} p=0 \cdot 09 . \dagger p<0 \cdot 001 . \neq p=0 \cdot 004 . . \mathrm{p}=0 \cdot 003$
Behavioural and disease variables examined as possible risks for HIV infection

BEHAVIOURAL VARIABLES

Homosexual lifestyle ( $>5$ years)

Total number of partners throughout life $(>50)$

Partners in past year $(>20)$

Casual partners:

Anopenetrative penis

Anopenetrative tongue

Anopenetrative fist

Anoreceptive penis

Anoreceptive tongue

Anoreceptive fist

Anal retention of semen

Swallowing of semen

American sexual partner in past two years

European sexual partner in past two years

Anal bleeding after sex in past two years

Use of drugs during sex

DISEASE VARIABLES

History of:

Syphilis

Hepatitis

Gonorrhoea

Non-specific urethritis or chlamydial infection

Anogenital herpes

Anogenital warts

Glandular fever

Positive result of Treponema pallidum haemagglutination test

Positive for antibody to hepatitis B surface antigen or for hepatitis B surface antigen

In view of their strong association with HIV infection on univariate analysis, being positive for antibodies to hepatitis B and for syphilis together with a history of the common sexually transmitted diseases were introduced into the logistic regression. Table IV shows that both infection with hepatitis B (defined serologically) and a history of syphilis had a high degree of additional predictive power for HIV infection $(p<0.001)$. A history of anogenital herpes also survived logistic regression $(p<0 \cdot 05)$. These variables displaced a homosexual lifestyle for more than five years as independent risks, suggesting that this behavioural variable derived its power as a function of the liability to acquire sexually transmitted infections. The survival in logistic regression of a history of glandular fever might be attributable to a similar illness sometimes seen at seroconversion. Clearly a model produced by stepwise logistic regression analysis cannot be interpreted as showing the absolute truth about the relevance of specific variables as several alternative models would also fit the data. Most of the differences, however, can be explained by changes in sexual behaviour after the study began and are consistent with clinical experience.

The failure of a positive result on testing for syphilis to show additional predictive power for HIV infection was investigated by listing those patients who had a history of syphilis but whose haemagglutination test gave a negative result. We found 11 patients with a previously positive result to the haemagglutination test whose results had become consistently negative. All 11 were positive for HIV antibody, representing $7 \cdot 6 \%$ (11/144) of the men confirmed to have had syphilis and to have HIV infection.

\section{TRENDS IN RISK FACTORS}

Table II shows changes in the proportion of patients with independent risk factors by period of presentation and the trends in serologically diagnosed 
TABLE III - Relative risks by stepwise logistic regression of $H I I^{\prime}$ infection, hepatitis $B$, and syphilis

\begin{tabular}{lccc}
\hline & \multicolumn{3}{c}{ Relative risk (95\% confidence interval) } \\
\cline { 2 - 4 } \multicolumn{1}{c}{ Behavioural variables } & HIV & Hepatitis B & Syphilis \\
\hline $\begin{array}{l}\text { Men with }>5 \text { years of homosexual } \\
\text { lifestyle }\end{array}$ & $1.95(1.24$ to 3.05$)$ & $2.56(1.81$ to 3.62$)$ & $4.60(2.66$ to 7.96$)$ \\
$\begin{array}{l}\text { Men with }>50 \text { sexual partners } \\
\text { throughout life }\end{array}$ & $2.30(1.57$ to 3.37$)$ & $2.59(1.92$ to 3.49$)$ & $3.45(2.39$ to 4.97$)$ \\
$\begin{array}{l}\text { Men who participated in anoreceptive } \\
\text { intercourse }\end{array}$ & $2.41(1.61$ to 3.62$)$ & $1.41(1.04$ to 1.91$)$ & \\
$\begin{array}{l}\text { Men who participated in anoreceptive } \\
\text { fisting }\end{array}$ & $1.60(1.17$ to 2.19$)$ & & $1.81(1.15$ to 2.86$)$ \\
$\begin{array}{l}\text { Men who used drugs during } \\
\text { intercourse }\end{array}$ & $2.03(1.28$ to 3.20$)$ & $1.83(1.28$ to 2.62$)$ & \\
$\begin{array}{l}\text { Result of Hosmer-Lemeshow test for } \\
\text { goodness of fit }\end{array}$ & $\gamma=13.52, \mathrm{df}=8, \mathrm{p}=0.096 \quad \gamma=4.67, \mathrm{df}=6, \mathrm{p}=0.587 \quad \gamma^{:}=9.22, \mathrm{df}=5, \mathrm{p}=0.1$
\end{tabular}

^Positive result of Treponema pallidum haemagglutination test.

TABLE IV-Relative risks by stepwise logistic regression of $\mathrm{HIV}$ infection with previous sexually transmitted diseases included in the model

\begin{tabular}{lc}
\hline \multicolumn{1}{c}{ Variables } & $\begin{array}{c}\text { Relative risk } \\
(95 \% \text { confidence interval })\end{array}$ \\
\hline History of syphilis & $2.33(1.68$ to 3.25$)$ \\
Anoreceptive intercourse & $2.23(1.47$ to 3.37$)$ \\
Infection with hepatitis B virus & $1.89(1.33$ to 2.68$)$ \\
More than 50 partners throughout life & $1.86(1.26$ to 2.74$)$ \\
Anoreceptive fist & $1.84(1.15$ to 2.97$)$ \\
History of glandular fever & $1.62(1.02$ to 2.57$)$ \\
History of anogenital herpes & $1.55(1.01$ to 2.39$)$ \\
Use of drugs during intercourse & $1.42(1.03$ to 1.97$)$ \\
\hline
\end{tabular}

Hosmer-Lemeshow test for goodness of fit: $\gamma^{:}=6 \cdot 02, \mathrm{df}=8, \mathrm{p}=0 \cdot 645$.

sexually transmitted infections. With the exception of a homosexual lifestyle practised for more than five years all these variables showed a significant downward trend overall $(\mathrm{p}<0.001)$. These trends were largely evident from November 1984 to December 1986. The final two cohorts showed reversed trends for partners in the past year and the use of drugs during intercourse.

\section{BISEXUAL BEHAVIOUR}

Bisexual activity was graded according to the interval since last heterosexual intercourse. The proportion of patients who had had heterosexual intercourse in the previous year remained constant over the study at about $10 \%$ (mean $10 \cdot 2$; range $7 \cdot 6-11 \cdot 5 \%)$. Likewise, the proportion of patients who had had heterosexual intercourse in the previous three years remained at about $20 \%(19 \cdot 2$; range $16 \cdot 4-23 \cdot 6 \%)$. The proportion of each cohort who had had heterosexual intercourse within these two periods and were positive for HIV antibody was $1 \cdot 0 \%$ (range $0 \cdot 6-1 \cdot 4 \%$ ) and $2 \cdot 7 \%(1 \cdot 4-3 \cdot 3 \%)$ respectively.

Table $\mathrm{V}$ shows the frequency distribution of heterosexual activity, expressed as months since heterosexual intercourse, and the number of men positive for HIV antibody in each group. There was a bimodal distribution of sexuality, with a small group frequently bisexual (about 5\%) and the rest either never having been heterosexual or having been so for a period earlier in life. More importantly, the acquisition of HIV infection was more common in the exclusively or predominantly homosexual group $(30 \%$ positive for HIV antibody) compared with the frequently heterosexual group ( $5 \%$ positive for HIV antibody).

TABLE $\mathrm{v}-$ Frequency distribution of heterosexual activity and proportion positive for HIV antibody among homosexual men

\begin{tabular}{|c|c|c|c|c|c|c|c|c|c|c|}
\hline & \multicolumn{10}{|c|}{ Months since last heterosexual intercourse } \\
\hline & 1 & $2-3$ & $4-6$ & $7-11$ & $12-23$ & $24-35$ & $36-59$ & $60-119$ & $120+$ & Never \\
\hline \multirow{2}{*}{$\begin{array}{l}\text { No }(\%) \text { of patients } \\
\text { No }(\%) \text { positive for } \\
\text { HIV antibody }\end{array}$} & $57(5)$ & $16(2)$ & $20(2)$ & $24(2)$ & $39(4)$ & $56(5)$ & $95(9)$ & $137(13)$ & $230(22)$ & $375(36)$ \\
\hline & $3(5)$ & $2(13)$ & $4(20)$ & $5(21)$ & $7(18)$ & $10(18)$ & $20(21)$ & $40(29)$ & $69(30)$ & $113(30)$ \\
\hline
\end{tabular}

\section{Discussion}

Control of the current epidemic of HIV infection in Western society will not be achieved without changes in the sexual behaviour of a section of the male homosexual population. To assess whether this is happening presents considerable problems in sampling and methodology because of the general unacceptability of random sampling of the population at risk. A large cohort of men known to have practised high risk behaviour could be monitored over time to document modifications in their lifestyle. Unfortunately such a study would be subject to bias from the essential compliance of this cohort and the favourable responses likely to be engendered by repeated counselling (to omit this would be unethical). We therefore examined men who were attending a clinic for their first test for HIV and had not to our knowledge been individually counselled about safe sex beforehand."

During the study we observed a highly significant $(p=0.004)$ fall in the proportion of men positive for HIV antibody together with the proportion positive for both hepatitis $B$ infection $(p<0 \cdot 001)$ and syphilis $(\mathrm{p}<0.001)$, which paralleled a lower rate of high risk activities and independent risk factors as previously defined. A causal relation is inescapable, but the proposition that this reflects a modification of behaviour over time requires additional support. We attempted to establish this by studying those behavioural and other variables not the subject of health education programmes (the age of the patients, their innate sexuality, and their inclination to form regular sexual partnerships), all of which remained unchanged throughout the study. On this basis we suggest that there has been a genuine and considerable modification in sexual lifestyle by a large proportion of homosexual men and that as a consequence the incidence of sexually transmitted infections, including HIV, has fallen. The profound consequences of HIV infection might have been expected to suppress the expression of a homosexual lifestyle in younger men. ${ }^{10}$ Our findings, however, show no decrease in the proportion of men who entered this lifestyle after the threat of HIV infection became apparent.

Several of the independent risk factors we have described raise the possibility that various mechanisms may predispose people to HIV infection. The use of nitrites, for instance, may facilitate the acquisition of infection through the rectal mucosa by hyperaemia or some other pharmacological action. "I2 The independent risk of having acquired syphilis, hepatitis $B$, or anogenital herpes could be explained by a genetically determined susceptibility to certain microbial infections s.14 $^{13}$ or an immunological mechanism associated with an activated immune system. ${ }^{15}$ Our data support the second alternative as we found that syphilis and hepatitis B ranked with anoreceptive intercourse as the strongest independent predictors of -HIV infection. These or similar infections may be even more relevant to heterosexual transmission of HIV in equatorial Africa. The most plausible explanation for the risk attributable to anoreception of the fist is that it causes local trauma to the skin and mucous membranes and so facilitates epithelial penetration.

Although hepatitis B and syphilis shared relative risks for HIV infection (duration of homosexual lifestyle and total number of sexual partners), they also showed differences. Anoreceptive intercourse is a risk for hepatitis B as well as HIV but not for syphilis; the same applies to the use of drugs, which may indicate that use of drugs relates to the rectal route of infection. Overall, hepatitis B is epidemiologically closer to infection with HIV. The study also showed some other aspects of the relation between homosexual lifestyle and HIV infection. Actively bisexual men are less 
likely to be infected than exclusively homosexual men, and our data suggest that two distinct populations may exist. In general the prevalence of HIV infection in homosexual men clearly exaggerates the risk of heterosexual spread from this source.

The part played by the information campaign funded by the government in bringing about modifications in homosexual lifestyle seems to have been small. The most substantial changes had occurred before the campaign started, and the reduced trend towards safer practices in the most recent cohort may be attributable to the government's reluctance to target the homosexual community in its subsequent publicity. Although selection of partners and use of condoms may militate against transmission of HIV, at risk behaviour is clearly still taking place, and more effort is required to reduce it to the best attainable minimum.

We thank Dr Berge Azadian for handling the serum samples, Dr Jonathan Coleman for data on hepatitis B, Marion Hudson for preparing the graphs, Helenlouise Taylor for data handling, and Sarah O'Connor for typing the manuscript.

I Goedert JJ, Sarngadharan MG, Biggar RT, et al. Determinants of retrovirus (HTLV-IIL) antibody and immunodeficiency conditions in homosexual men. Lancet 1984;ii:711-6.
2 Evans BA, Dawson SG, McLean KA, et al. Sexual lifestyle and clinical findings related to HTLV-III/LAV status in homosexual men. Genitourin Med 1986;62:384-9.

3 Winkelstein W, Liman DM, Padian N, et al. Sexual practices and risk of infection by the human immunodeficiency virus. The San Francisco men's infection by the human immunodeficienc

4 Kingsley LA, Detels R, Kaslow R, ct al. Risk factors for seroconversion to human immunodeficiency virus among male homosexuals. Results from the multicentre AIDS cohort study. Lancet 1987;ii:345-9.

5 Department of Health and Social Security. AIDS: don't die of ignorance. London: DHSS, 1987

6 Mortimer PP, Parry JV, Mortimer JY. Which anti-HTLV III/LAV assays for screening and confirmatory testing? Lancet 1985; ;i: $873-8$.

7 Dixon WJ, ed. B.MIDP statistical software. Berkelev: University of California, 1983.

8 Hill AB. A short textbook of medical statistics. London: Hodder and Stoughton, 1977

9 Goedert JJ. Sounding board: what is safe sex? N Engl f Med 1987:316: $1339+42$.

10 Remafedi G. Homosexual vouth. A challenge to contemporary society. f AMA $_{1}$ 1987;258:222-5

11 Niedecken N, Lutz G, Bauer R, Krevsel HW. Langerhans cell as primary target and vehicle for transmission of HIV. Lancet 1987;ii:519-20.

12 Nelson JA, Wilev CA, Reynolds-Kohler C, Reese CE, Margaretten W', Lewy $J A$. Human immunodeficiency virus detected in bowel epithelium from patients with gastrointestinal symptoms. L Lancet 1988;i:259-62.

13 Eales L-J, Nye KE, Parkin JM, et al. Association of different allelic forms of group specific component with susceptibility to and clinical manifestation of human immunodeficiency virus infection. Lancet 1987;i:999-1002.

14 Eales L-J, Nye KE, Pinching AJ. Group specific component and AIDS erroneous data. Lancet 1988; ; 936 .

15 Weber JN, McCreaner A, Berrie E, et al. Factors affecting seropositivity to human T cell lymphocytic virus type III (HTLV-III) or lymphadenopath associated virus $(\mathrm{LAV})$ and progression of disease in sexual partners of patients with AIDS. Genitourin .Med 1986;62:177-80.

Accepted 17 November 1988

\title{
Changes in sexual behaviour and the fall in incidence of HIV infection among homosexual men
}

\author{
Godfried J P van Griensven, Ernest M M de Vroome, Jaap Goudsmit, Roel A Coutinho
}

Department of Infectious Diseases, Municipal Health Service, PO Box 20244, $1000 \mathrm{HE}$ Amsterdam, The Netherlands Godfried J P van Griensven, MS, methodologist Roel A Coutinho, MD, microbiologist

\section{Department of Studies on Homosexuality, State University of Utrecht, Utrecht, The Netherlands Ernest M M de Vroome, MS, psychologist}

Department of Virology, University of Amsterdam, Amsterdam, The Netherlands

Jaap Goudsmit, MD, virologist

Correspondence and requests for reprints to: $\mathrm{Dr}$ van Griensven.

\begin{abstract}
To investigate the epidemiology and normal course of infection with HIV the prevalence and incidence of the infection were studied among two cohorts of homosexual men in Amsterdam in 1980-7. The cumulative incidence of infection increased from a weighted $2 \cdot 2 \%$ in 1980 to $39.0 \%$ in 1987 . The estimated yearly incidence of HIV was $3.0 \%$ in 1981 , rose to $8.8 \%$ in 1984 , and fell gradually to $0 \%$ in 1987 . During the study the sexual behaviour of the cohorts was examined. The number of men with whom anopenetrative intercourse was practised fell from a mean of 10.6 to 1.4 for those positive for HIV antibody, whereas the number with whom anoreceptive intercourse was practised fell from a mean of $3 \cdot 7$ to 0.5 for those negative for the antibody. In addition, there was a reduction in the number of cases of hepatitis $B$ and syphilis among men in general.
\end{abstract}

The decline in infection with HIV was assumed to be linked to changes in sexual behaviour. Such changes practised early in the course of the epidemic probably had a strong effect on the number of cases of AIDS among homosexual men in Amsterdam.

\section{Introduction}

In 1982 the first case of AIDS in The Netherlands was diagnosed in a homosexual man. ${ }^{\prime}$ By April 1988 , 487 cases had been reported, of which 413 were in homosexual men. ${ }^{2}$ To investigate the epidemiology and the natural course of infection with HIV a cohort study was started in October 1984 among 746 homosexual men in Amsterdam. Earlier epidemiological, clinical, and immunological results of this study have been reported. ${ }^{3-6}$ This paper reports the cumulative incidence of HIV infection in this cohort in relation to changes in sexual behaviour. In addition the probable course of the spread of HIV in this cohort was assessed by reconstructing the epidemiological curve over the past seven years. This reconstruction was based on the retrospectively determined prevalence and incidence of HIV infection in a cohort of homosexual men who participated in a trial of hepatitis B vaccine in $1980-2 .^{7 *}$

\section{Subjects and methods}

STUDY POPULATION

Two cohorts were studied. The first comprised 746 homosexual men who were participating in a prospective study of HIV infection and AIDS that started in October 1984 (the AIDS cohort study)..$^{3-6}$ The second comprised 685 men who participated in a placebo controlled trial of the efficacy of a heat inactivated hepatitis B vaccine from November 1980 to November $1982 .{ }^{78}$ In both cohorts participants were healthy male homosexual volunteers, most of whom lived in and around Amsterdam. Participants in the hepatitis $B$ vaccine trial were negative for markers of hepatitis B infection. The design of these studies, as well as demographic and other characteristics of the participants, have been described previously. ${ }^{3.8}$

\section{CONDUCT OF THE STUDY}

Participants in the AIDS cohort study were enrolled from October 1984 to May 1985 and were seen every three months at the Municipal Health Service of Amsterdam. This study covers data collected until October 1987. When they entered the study subjects were physically examined and their medical history was taken. Every three months blood samples were collected for virological and immunological tests. Presence of antibody to HIV was established with two enzyme linked immunosorbent assays (ELISA; Organon, Oss, The Netherlands, and Abbott, north Chicago, United States) and confirmed by immuno- 